of sensitivity of the IEF technique as suggested by others. We also tried the modified technique of Wilson et al. (10) with a $\mathrm{pH}$ 2.5-10.0 gradient instead of a pH 5-10 gradient and with a prefocus $30 \mathrm{~min}$ at 300 volts, but the detection of the CFP band was not improved.

Recently, this CFP specific material, isolated from polyacrylamide gel after electrofocusing, has been used with success by different groups to develop a quantitative immunoassay. Manson and Brock $(1,2)$ have raised antisera in guinea pigs and Wilson in mice (12). Both antisera allowed a quantitative distinction between CF homozygotes, heterozygotes, and controls. Even if there are still a number of unsolved problems such as blood collection and antiserum supply (1), their data, which shows a difference in levels of CFP strongly argue that this protein may be a marker of cystic fibrosis. Our characterization of CFP in plasma as well as in serum demonstrates that this low molecular weight protein is present in blood before blood clotting and could permit a better standardization of blood collection, which looks critical for its evaluation.

In conclusion, we agree with many workers that the IEF technique is too delicate and not sufficiently sensitive to be used for diagnosis. This technique remains, however, the first step in identifying the CFP which seems to be closely associated with the $\mathrm{CF}$ gene and whose characterization would allow future investigation of the basic defect of the disease.

\section{RFFERENCES AND NOTES}

1. Bullock, S. Havward C Manson, J. Brock. D J. H. and Rachurn, J. A Quantitative immunoassays for diagnosis and carrier detection in cystic fibrosis. Clin. Genet.. 21: 336 (1982)

2. Manson. J. C. and Brock. D. J. H.: Development of a quantitative immunoassay for the cystic tibrosis gene. Lancet. Feb. 16:330(1980).
3. Nevin G. B Nevin N.C. and Remond, A. O. Cystic fibrosis in Northern Ireland. J. Med. Genet., J6: 122 (1979).

4. Nevin. G. B., Nevin, N. C.. Redmond, A. O., Young, I. R., and Tully, G. W. Detection of cvstic fibrosis homozygotes and heterozygotes by serum isoelectrofocusing. Hum. Genet.. 56: 387 (1981).

5. Scholey, J.. Applegarth. D. A.. Davidson, A. G. F.. and Wong. L. T. K.: Detection of cystic fibrosis protein by electrofocusing. Pediatr. Res. 12: 800 (1978).

6. Steinberg. A. G. and Brown, D. C.: On the incidence of cystic fibrosis of the pancreas. Am. J. Hum Genet. 12: 416 (1960).

7. Thomas J. M Mcritt A. D and Hodes, M. E. Electrophoretic analysis of serum protein in cystic fibrosis. Pediatr. Res., 11: 1148 (1977).

8. Wilson, G. B., Jahn, T. L., and Fonseca, J. R.: Demonstration of serum protein differences in cystic fibrosis by isoelectric focusing in thin-layer polyacrylamide gels. Clin. Chim. Acta. 49: 79 (1973).

9. Wilson. G. B. Fudenberg H. H. and Jahn . T. L.: Studics on cystic fibrosis using isolelectric focusing. An assay for detection of cystic fibrosis homozygotes and heterozygote carriers from serum. Pediatr. Res. 9: 635 (1975).

10. Wilson. G. B.. Arnaud. P. and Fudenberg. H. H.: Improved method for detection of cystic fibrosis protein in serum using LKB multiphor electrofocusing apparatus. Pediatr. Res. 11: 986 (1977)

11. Wilson, G. B.: Cystic fibrosis protein, a confirmed diagnosis marker for detecting heterozygote carriers: significance in relation to future screening and to a proposed primary defcet in alpha 2-macroglobulin. Pediatr. Res. 13: $1079(1979)$

12. Wilson. G. B.: Monospecific antisera. hybridoma antibodics, and immunoassays for cystic fibrosis protein. Lancet. 9: $313(1980)$

13. $\% \mathrm{~T}=$ grams of acrylamide + grams of bisacrylamide $/ 100 \mathrm{ml}$ of solution: \%C $=100$ times grams of bisacrylamide $/ 100 \mathrm{mi}$ solution $/ \mathrm{T}$. Nomenclature ac cording to Vesterberg. O. and NISE, G.: Urinary protcins studied by use of isoelectric focusing. 1/ Tubular malfunction in association with exposure to cadmium Clin Chem. 19: 1179 (1973).

14. The authors thank J. P. CHAZALETTE (Giens), R. GILLY and I. GARCIA (Lyon) for supplying them with sera and plasma. A grant from the AFLM (Association Française de lutte contre la mucoviscidose) is gratefully acknowl ediged.

15. Requests for reprints should be addressed to: Doctor Catherine Figarella INSERM U-31, 46. Boulevard de la Gaye, 13258 MARSEILLE CEDEX 09 (FRANCE).

16. Received for publication January 12.1983.

17. Accepted for publication August 17.1983

\title{
Changes in the Growth-Promoting Activity of Human Milk during Lactation
}

\author{
LEANNA C. READ ${ }^{(37)}$ FAYE M. UPTON. GEOFFREY L. FRANCIS, JOHN C. WALLACE. \\ GEOFFREY W. DAHLENBERG, AND F. JOHN BALLARD
}

CSIRO Division of Human Nutrition [L.C.R., G.L.F., F.J.B.J, University of Adelaide, Departments of Biochemistry [F.M.U., J.C.W.J, and Pediatrics [G.W.D.] Adelaide, S.A. 5000, Australia

\section{Summary}

We measured the concentrations of protein, insulin, and epidermal growth factor (EGF) in human milk from mothers delivering at term. Samples were obtained from $\mathrm{d} \mathbf{l}$ (colostrum) to $\mathrm{d}$ 42 after birth. Human colostrum contains very high concentrations of protein $[83.7 \pm 7.4 \mathrm{~g} / \mathrm{l}(\mathrm{SEM})]$, insulin $(3.75 \pm 0.88$ $\mathrm{nM}$ ), and EGF (53.9 $\pm 6.9 \mathrm{nM})$. Similar concentrations have been measured in prebirth milk. Insulin, EGF, and protein in milk decline rapidly during the first few days of lactation but remain constant thereafter. Although the concentrations of insulin and EGF in mature milk are only $10 \%$ of those in colostrum, they are considerably higher than in serum. We also showed that human milk has a growth-promoting activity in cultured cells, causing a stimulation of protein synthesis in L6 myoblasts and
3T3-L1 fibroblasts and an increase in DNA synthesis in L6 cells and T47D breast cancer cells. This mitogenic activity declines as lactation progresses, with a similar time-course to the fall in insulin and EGF; however, the cell lines used here are not responsive to either of these two growth factors in the range of concentrations found in milk. This indicates that human milk also contains high concentrations of additional, unidentified growth factors. The occurrence of high concentrations of growth factors in milk suggests that they may be important for the proliferation and differentiation of infant tissues.

\section{Abbreviations}

EGF, epidermal growth factor

PBS, phosphate buffered saline 
A wide spectrum of hormones has been identified in milk, including prolactin, prostaglandins, thyroid hormones, glucocorticoids, thyroid stimulating hormone, and adrenocorticotropic hormone (20). More recently, milk has been shown to contain high concentrations of factors that promote the growth of cultured cells. Klagsbrun (17) first reported in 1978 that human milk contained a mitogenic factor that stimulated DNA synthesis and cell division in mouse and human fibroblasts in vitro, $1 \%$ milk having the potency of $10 \%$ fetal calf serum. Subsequent studies have shown that the response can be demonstrated in several cell types $(2,7,18,28,31)$ and that bovine colostrum is more active than mature milk $(2,18,31)$. EGF is one of the major growth-promoting factors in milk because most of the mitogenic activity of human milk on cultured human fibroblasts is lost after addition of antibodies against EGF (7). Insulin also has a growth-promoting role because passage of colostrum through a column containing anti-insulin antibodies eliminates the inhibition of intracellular protein degradation in $\mathrm{H} 35$ and $\mathrm{MH}_{1} \mathrm{C}_{1}$ hepatoma cells produced by unfractionated colostrum (2). It is apparent, however, that milk also contains other growth factors because colostrum is mitogenic in cultured cell lines that show little response to insulin or EGF (2).

The growth-promoting action of milk on cultured cells and the high concentration of EGF, and possibly of insulin, suggest that growth factors in milk may play an important role in the growth and differentiation of infant tissues. Accordingly, we have measured changes during lactation in the concentration of insulin and EGF in human milk and correlated these changes with its growth-promoting activity, estimated as the stimulation of DNA and protein synthesis in cultured cells.

\section{MATERIALS AND METHODS}

Milk samples. Samples of expressed breast milk were obtained from 23 mothers after delivery of full-term infants. The mean gestational age was $40 \mathrm{wk}$ (range, 38-41 wk) and all pregnancies were considered normal and without significant maternal disease. Samples were taken daily for the first week after birth, and then weekly for a further $5 \mathrm{wk}$, with 18 of the 23 mothers completing the entire $6 \mathrm{wk}$ collection period. Milk expressed before birth was also obtained from some women. All samples were expressed manually into polypropylene tubes and frozen $\left(-15^{\circ} \mathrm{C}\right)$ immediately. Subsequently they were thawed, diluted with an equal volume of PBS comprising $10 \mathrm{mM} \mathrm{KH}_{2} \mathrm{PO}_{4}$ and $0.9 \%(\mathrm{w} / \mathrm{v})$ $\mathrm{NaCl}, \mathrm{pH} 7.4$, and centrifuged at $100,000 \mathrm{~g}$ for $60 \mathrm{~min}$. The infranatants were recovered by aspiration and stored at $-15^{\circ} \mathrm{C}$.

Cell culture. L6 rat myoblasts, 3T3-L1 mouse fibroblasts, and AG2804 Simian virus 40-transformed human lung fibroblasts were kindly provided by Dr. J.M. Gunn, Department of Biochemistry and Biophysics, Texas $\mathrm{A}$ and $\mathrm{M}$ University, College Station, TX and T47D human cancer breast cells by Professor T.J. Martin, Department of Medicine, University of Melbourne, Repatriation General Hospital, West Heidelberg, Victoria 3077, Australia.

Uniform numbers of cells were added to Costar 24-well plates, and grown in Dulbecco-modified Eagle's minimal essential medium containing $5 \%(\mathrm{v} / \mathrm{v})$ fetal calf serum together with $50 \mathrm{mg}$ gentamycin, $100 \mathrm{mg}$ streptomycin sulphate, and $60 \mathrm{mg}$ penicillin $\mathrm{G}$ per litre (growth medium). All measurements were carried out on confluent monolayers.

Measurement of insulin concentration. Insulin in milk infranatants was determined by radioimmunoassay (12) with porcine insulin as the standard. Identical concentrations were measured using human insulin standard (results not shown). [ $\left.{ }^{125} \mathrm{I}\right]$ Insulin (specific activity, $50 \mu \mathrm{Ci} / \mu \mathrm{g}$ ) was prepared using 1,3,4,6-tetrachloro-3 $\alpha, 6 \alpha$-diphenylglycoluril (Iodogen) (11).

Measurement of EGF. EGF was measured by a radioreceptor assay using murine EGF as the standard together with $\left[{ }^{125} \mathrm{I}\right]$ labeled murine EGF. EGF was iodinated to a specific activity of $50 \mu \mathrm{Ci} / \mu \mathrm{g}$ using the Iodogen method (11). Binding of EGF to monolayers of AG2804 fibroblasts (approximately $150 \mu \mathrm{g}$ protein per monolayer) was determined in triplicate in Hanks' salts, $\mathrm{pH}$ 7.4 containing $0.1 \%(\mathrm{w} / \mathrm{v})$ bovine serum albumin. Confluent monolayers were washed twice with this solution over a period of $60 \mathrm{~min}$ at $37^{\circ} \mathrm{C}$. Fresh salts containing [125 I]EGF (approximately $0.8 \mathrm{ng}, 0.04 \mu \mathrm{Ci}$ ) and standard EGF or milk infranatants were then added in a total volume of $500 \mu \mathrm{l}$. Dishes were incubated at $24^{\circ} \mathrm{C}$ for $90 \mathrm{~min}$ before being washed five times at $4^{\circ} \mathrm{C}$ with Hanks' salts without albumin. Monolayers were dispersed by trituration in $1 \mathrm{ml}$ of $0.5 \mathrm{M} \mathrm{NaOH}$ containing $0.1 \%$ $(\mathrm{w} / \mathrm{v})$ Triton $\mathrm{X} 100$ for the measurement of radioactivity and protein.

Protein synthesis measurements. Monolayers of L6 myoblasts and 3T3-L 1 fibroblasts were incubated at $37^{\circ} \mathrm{C}$ with $1 \mathrm{ml}$ of labeling medium (serum-free growth medium to which $0.5 \mathrm{mmol}$ of leucine had been added per litre). After $2 \mathrm{~h}$, fresh labeling medium containing $1 \mu \mathrm{Ci}\left[{ }^{3} \mathrm{H}\right]$ leucine and the sample to be tested $(100 \mu \mathrm{l})$ were added in a total volume of $1 \mathrm{ml}$. Samples included milk infranatants, purified growth factors or fetal calf serum. Control wells contained $100 \mu \mathrm{l}$ PBS. Dishes were incubated for $18 \mathrm{~h}$ at $37^{\circ} \mathrm{C}$ with a gas phase of $5 \% \mathrm{CO}_{2}$ in air before the medium was removed, and the monolayers washed twice with $1 \mathrm{ml} 5 \%(\mathrm{w} / \mathrm{v})$ trichloroacetic acid during a 10 -min period. Monolayers were finally rinsed with $2 \mathrm{ml}$ distilled water before digestion in $1 \mathrm{ml} 0.5 \mathrm{M} \mathrm{NaOH}$ containing $0.1 \%(\mathrm{w} / \mathrm{v})$ Triton $\mathrm{X} 100$. Radioactivity was measured after trituration using an NCS-based scintillation fluid (19). Total radioactivity in these digests was interpreted as radioactivity in cell protein because it was found that material soluble in trichloroacetic acid contained insignificant amounts of label. Protein synthesis was expressed as counts/min of $\left[{ }^{3} \mathrm{H}\right]$ leucine incorporated into cell protein.

Measurement of DNA synthesis. Monolayers of L6 myoblasts and T47D breast cancer cells were washed for $2 \mathrm{~h}$ at $37^{\circ} \mathrm{C}$ with $1 \mathrm{ml}$ labeling medium containing $5 \mu \mathrm{M}$ thymidine. This was then replaced by $900 \mu$ l fresh medium together with $100 \mu$ l PBS (controls) or sample as described for protein synthesis. Cultures were incubated at $37^{\circ} \mathrm{C}$ for $18 \mathrm{~h}$ before addition of $1 \mu \mathrm{Ci} / \mathrm{ml}$ of $\left[{ }^{3} \mathrm{H}\right]$ thymidine. After a further $6-\mathrm{h}$ incubation at $37^{\circ} \mathrm{C}$, monolayers were washed, digested, and counted as for protein synthesis.

Protein determinations. Protein concentrations in milk infranatants and in digested cell monolayers were measured by an Auto Analyser adaptation of the method of Dulley and Grieve (10), who used bovine serum albumin as the standard.

Materials. Culture media were purchased from Gibco, Grand Island, NY, U.S.A. and fetal calf serum from Commonwealth Serum Laboratories, Melbourne, Australia. Iodogen was obtained from Pierce Chemical Co., Rockford, IL, U.S.A.; Na[ $\left.{ }^{125} \mathrm{I}\right]$ (16 $\mathrm{mCi} / \mu \mathrm{g}$ iodide), $\mathrm{L}-\left[4,5-{ }^{3} \mathrm{H}\right]$ leucine $(40-60 \mathrm{Ci} / \mathrm{mmol})$, and [methyl- ${ }^{3} \mathrm{H}$ ] thymidine $(20 \mathrm{Ci} / \mathrm{mmol})$ were from the Radiochemical Centre, Amersham, U.K. Unlabeled insulin was Actrapid from Novo Industri A/S, Copenhagen, Denmark. EGF was generously provided by Dr. J.H. Koch, CSIRO, Molecular and Cellular Biology Unit, North Ryde, N.S.W., Australia. Antibodies used in insulin radioimmunoassays were obtained from Wellcome Australia Ltd., Roseberry, New South Wales, Australia and NCS solubiliser was a product of Amersham Corporation, Arlington Heights, Illinois, U.S.A. Sephadex G50 superfine resin was obtained from Pharmacia Fine Chemicals, Uppsala, Sweden.

\section{RESULTS}

Growth factors in milk. Evidence for the identity of the material assayed by radioreceptor and immunoassays was obtained by chromatographing human milk on a Sephadex G50 column as described in Figure 1. EGF and insulin were recovered quantitatively from the column and $90 \%$ of the activity measured by receptor (EGF) or radioimmunoassay (insulin) eluted in a single peak. Both insulin and EGF activity chromatographed slightly earlier than the [125]labeled standards, but because there was only a slight difference in elution volume, it appears likely that the material assayed in milk is insulin and EGF, and does not 
include any high molecular weight forms. The difference in chromatographic behaviour between unlabeled and $\left[{ }^{125} \mathrm{I}\right]$ peptides may result from effects of iodination on molecular weight, shape, and charge distribution.

Concentrations of EGF and insulin in milk infranatants were proportional to the volumes assayed. Added standards were recovered quantitatively in the presence of these samples (data not shown).

The concentration of insulin in day 1 colostrum shows considerable variability between mothers, with a range of $0.59-15.36$ $\mathrm{nM}$. Nevertheless, the concentration in all samples is much higher than that in serum; the mean $[3.75 \pm 0.88(\mathrm{SEM}) \mathrm{nM}, n$ $=18$ ] being approximately thirty times higher (26). The insulin

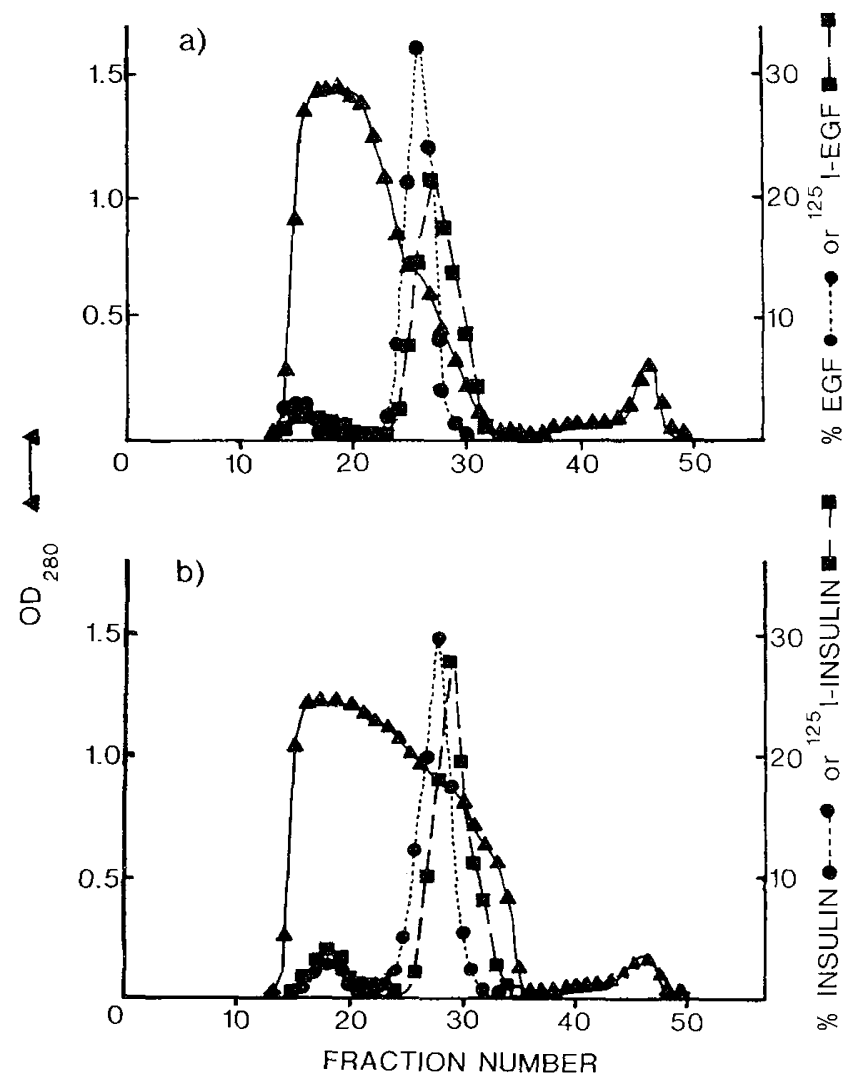

Fig. 1. Chromatographic profile of human milk on Sephadex G50. Milk infranatant $[1.0 \mathrm{ml}$ pre-birth milk containing $30 \mathrm{mg}$ protein, 200 ng epidermal growth factor (EGF) and $23 \mathrm{ng}$ insulin] together with $a$ ) $\left.{ }^{125} \mathrm{r}\right]-\mathrm{EGF}(0.08 \mathrm{ng}, 4000$ counts $/ \mathrm{min})$ or $\left.b\right)\left[{ }^{125} \mathrm{r}\right]$-insulin $(0.04 \mathrm{ng}, 3000$ counts/min) was applied to a $0.9 \times 60 \mathrm{~cm}$ column of Sephadex G50 superfine. equilibrated with phosphate buffered saline containing $1.5 \mathrm{mg} /$ $\mathrm{ml}$ bovine serum albumin. Elution was carried out in the same solution, at room temperature with a flow rate of $0.11 \mathrm{ml} / \mathrm{min}$. Fraction volume was $1 \mathrm{ml}$ and insulin, EGF and radioactivity were measured in each fraction. Over $90 \%$ of added EGF, insulin or $\left.\left[{ }^{125}\right]\right]$-peptides were recovered from the column. EGF and insulin contents of each fraction are expressed as a percentage of the total amount of peptide recovered from the column.

Table 1. Concentrations of insulin, epidermal growth factor $(E G F)$, and protein in prebirth milk and colostrum

\begin{tabular}{lccccccc}
\hline & \multicolumn{2}{c}{$\mathrm{l}$} & & & \multicolumn{2}{c}{2} & \\
\cline { 2 - 3 } \cline { 6 - 7 } & $-13 \mathrm{~d}^{*}$ & $\mathrm{~d} \mathrm{1}$ & & $-6 \mathrm{~d}^{*}$ & $-5 \mathrm{~d}^{*}$ & $\mathrm{~d} \mathrm{I}$ \\
\hline Insulin $(\mathrm{nM})$ & 7.73 & 6.72 & & 4.37 & 4.80 & 2.77 \\
EGF $(\mathrm{nM})$ & 38.7 & 46.7 & & 30.0 & 14.0 & 23.3 \\
Protein $(\mathrm{g} / \mathrm{l})$ & 61.2 & 70.4 & & 118.4 & 85.9 & 99.5 \\
\hline
\end{tabular}

* Refers to days before birth (d 1 ).
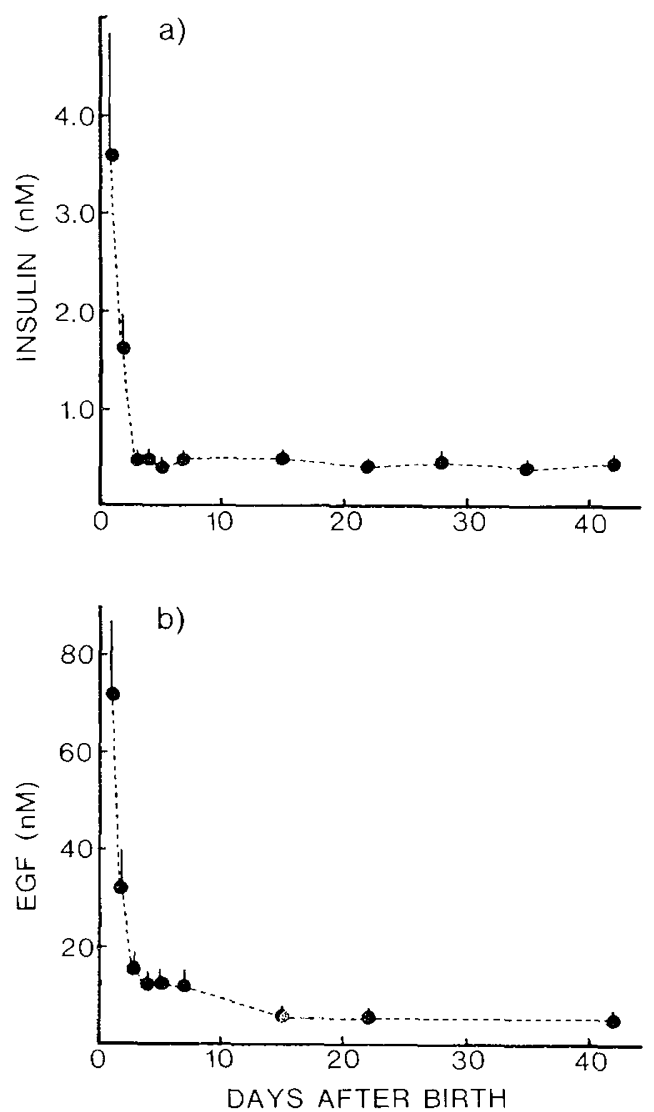

Fig. 2. Concentrations of $a$ ) insulin and $b$ ) EGF in undiluted. fat-free infranatants of human milk. Values are mean \pm SEM of five to seven determinations.

concentrations in pre-birth milk and colostrum are similar (Table 1). Figure $2 \mathrm{a}$ shows that the concentration of insulin in milk falls rapidly during the first $3 \mathrm{~d}$ of lactation and then shows no further decline. The basal level in mature milk $[0.46 \pm 0.05$ (SEM) nM, $n=18]$, measured after $42-46 \mathrm{~d}$ of lactation is only $16 \%$ of the concentration on the first day of lactation but is still several-fold higher than in serum.

The EGF concentrations in colostrum $[53.9 \pm 6.9$ (SEM) nM, $n=17]$ and pre-birth milk (Table 1) are approximately 2000fold greater than in serum (14). As with insulin, variability between mothers is high [range 23.3-125.0 nM in colostrum] and the EGF concentration declines rapidly during the first few days of lactation, although approximately $2 \mathrm{wk}$ are required to reach a basal concentration (Fig. 2b). The EGF content of mature milk $[4.9 \pm 0.4(\mathrm{SEM}) \mathrm{nM}, n=17]$, measured after $42-46 \mathrm{~d}$ of lactation is more than 100 -fold greater than in serum.

The protein concentration of human colostrum is $83.7 \pm 7.4$ (SEM) $g / 1$ fat-free infranatant $(n=18)$ and Table 1 shows that similar concentrations are found in pre-birth milk. There is a marked decline in protein during the first week of lactation to a basal concentration, which is $10 \%$ of that in colostrum (Fig. 3a). The concentrations of protein, insulin, and EGF fall at similar rates, so that insulin and EGF expressed per gram of protein show little change as lactation progresses (Fig. 3b).

Effects of milk on DNA and protein synthesis in cultured cells. In order to assess the growth-promoting activity of human milk in different tissues, we have used L6 myoblasts, 3T3-L1 fibroblasts, and T47D breast cancer cells that originate from muscle, adipose, and breast tissue, respectively. Human milk stimulates protein synthesis in both L6 myoblasts and 3T3-L1 fibroblasts (Fig. 4). Colostrum assayed at a concentration of $2 \%(\mathrm{v} / \mathrm{v})$ is nearly as potent as $5 \%(\mathrm{v} / \mathrm{v})$ fetal calf serum and a significant stimulation is apparent with $0.5 \%$ colostrum. This effect diminishes during the first $3 \mathrm{~d}$ of lactation although protein synthesis 

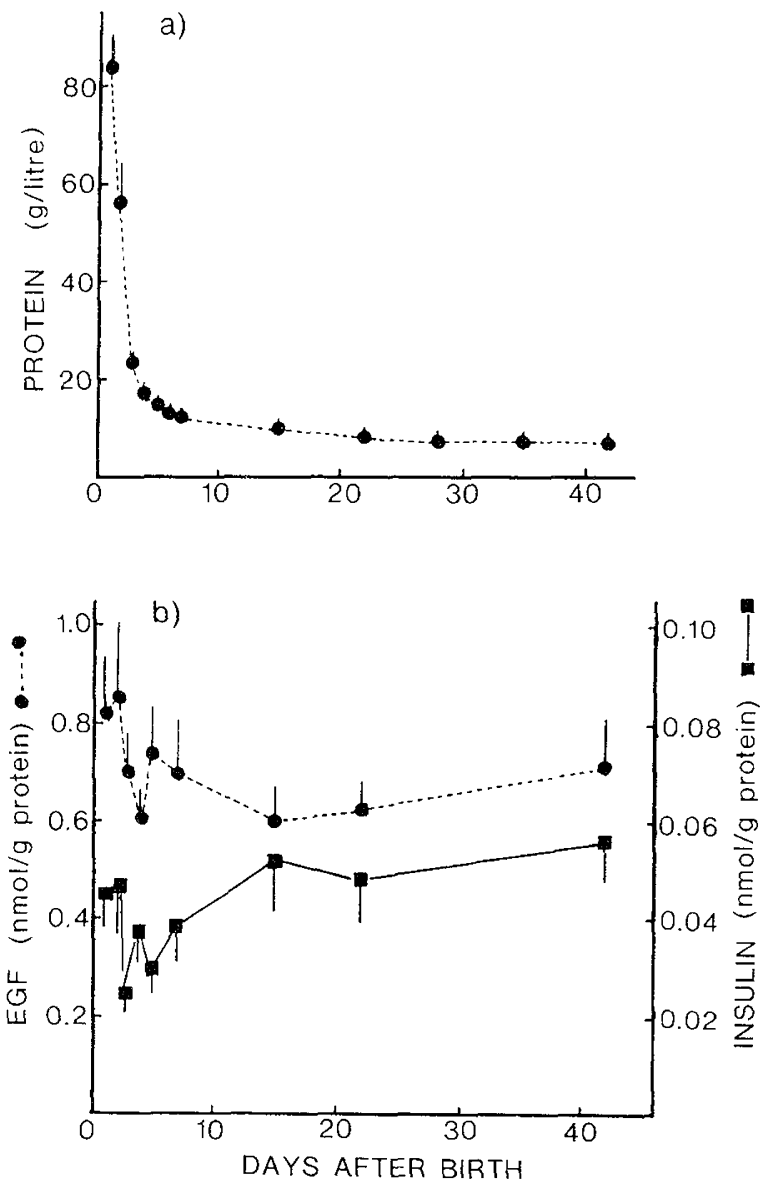

Fig. 3. a) Protein concentration in undiluted, fat-free infranatants of human milk. Data are presented as mean \pm SEM for $18-23$ samples. $b$ ) Insulin and EGF concentrations in human milk, expressed as nmol/g infranatant protein. Values are mean \pm SEM of five to seven determinations.

in the presence of $2 \%$ mature milk remains significantly higher than the control rate in both of these cell lines.

Colostrum at $2 \%$ increases the rate of DNA synthesis in L6 myoblasts to approximately $300 \%$ of the control value (Fig. 5a), but in contrast to its effects on protein synthesis, $2 \%$ colostrum is much less potent than $5 \%$ fetal calf serum in stimulating DNA synthesis in L6 cells and $0.5 \%$ colostrum has no significant effect. The stimulation of DNA synthesis by $2 \%$ milk declines over the first $5 \mathrm{~d}$ of lactation and milk obtained after this time reduced DNA synthesis in L6 myoblasts below the control rate.

A different response to milk is seen with DNA synthesis in T47D breast cancer cells. In this cell line, $0.5 \%$ colostrum produces a near-maximal stimulation of thymidine incorporation and is more potent than 5\% fetal calf serum (Fig. 5b). The stimulation of DNA synthesis by $2 \%$ milk declines only slightly as lactation progresses, but at a submaximal concentration $(0.5 \%)$, it is apparent that colostrum is more potent than mature milk.

Response of cultured cell lines to insulin and EGF. The high concentrations of insulin and EGF in human colostrum suggest that these growth factors may account for a large proportion of the stimulation by milk of DNA and protein synthesis in cultured cells. This has been tested by incubating cells in the presence of the concentrations of EGF and insulin in milk. In assays containing $2 \%$ milk, cells are exposed to EGF concentrations ranging from $10^{-9}$ (colostrum) to $10^{-10} \mathrm{M}$ (mature milk) and insulin concentrations of $5 \times 10^{-11}$ to $10^{-11} \mathrm{M}$ (Fig. 2). We have found that L6 myoblasts show little response to these growth factors; $10^{-12}-10^{-8}$ M EGF does not stimulate protein or DNA synthesis while no effect of insulin is observed until the concentration exceeds $10^{-7} \mathrm{M}$. Protein synthesis in 3T3-L1 fibroblasts responds to insulin but only at concentrations above $10^{-8} \mathrm{M}$. A small effect of EGF is discernible at $10^{-4} \mathrm{M}$ EGF but this could only account for $10 \%$ of the stimulation induced by $2 \%$ colostrum. The response to insulin and EGF in T47D cells is similar to that in 3T3-L1 fibroblasts. Insulin does not increase the rate of DNA synthesis until the concentration exceeds $10^{-7} \mathrm{M}$ and although an effect of EGF can be seen at concentrations as low as $10^{-4} \mathrm{M}$, this represents only $20 \%$ of the stimulation induced by $2 \%$ colostrum in T47D cells. Insulin and EGF were also added to cell cultures in combination and Table 2 shows that EGF and insulin do not contribute to the stimulation of DNA or protein synthesis in L6 myoblasts and can account for only $10 \%$ and $20 \%$ of the response to colostrum in $3 \mathrm{~T} 3-\mathrm{Ll}$ fibroblasts and T47D cells, respectively.

\section{DISCUSSION}

Our results show that human milk contains high concentrations of insulin and EGF. The insulin concentration in colostrum is 40 -fold greater than in serum and although this declines sharply during the first $3 \mathrm{~d}$ of lactation, it remains for at least $6 \mathrm{wk}$ at a concentration that is several-fold higher than in blood. A decline in insulin during lactation has also been observed by Cevreska et al. (8) but they reported much lower concentrations. The reasons for this quantitative difference are not apparent because assay procedures were similar.

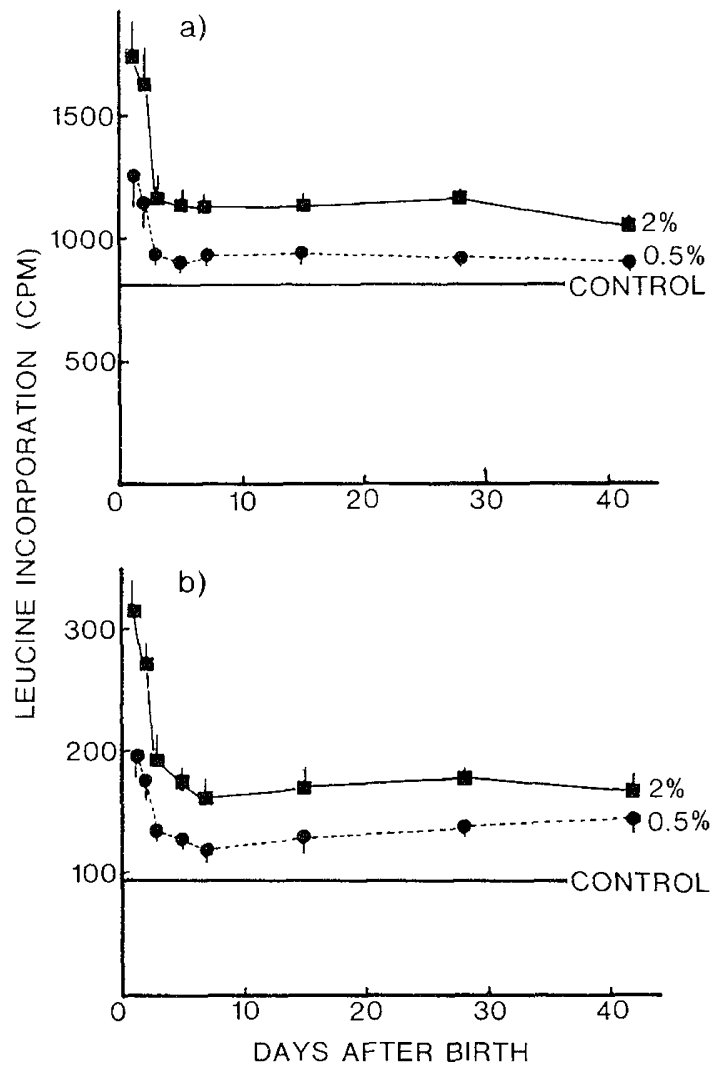

Fig. 4. Stimulation of protein synthesis in cultured cells by $0.5 \%$ and $2 \% \mathrm{v} / \mathrm{v}$ human milk. Rates of protein synthesis are expressed as counts/ min of $\left[{ }^{3}\right.$ Hlleucine incorporated into cellular protein. The mean of the control rates was determined and for each experiment; leucine incorporation in the presence of samples was normalized to this control rate. $a$ ) L6 myoblasts. Values are mean $\pm \mathrm{SEM}$ of five to seven samples. The rate of leucine incorporation with $5 \% \mathrm{v} / \mathrm{v}$ fetal calf serum was $2392 \pm$ 255 counts/min $(n=7)$ over the 18 -h incubation period. b) 3T3-L1 fibroblasts. Data are means \pm SEM, for four to five determinations. The rate with $5 \%$ fetal calf serum was $424 \pm 13$ counts $/ \min (n=5)$. 
EGF, in contrast to insulin, cannot be measured accurately by radioimmunoassay without use of homologous hormone as standard because anti-mouse EGF is less than $0.1 \%$ as reactive with human EGF as with mouse EGF (14). We have used a radioreceptor assay with cultured human AG2804 fibroblasts because interspecies differences are generally much less in receptor assays than with radioimmunoassays $(14,24)$. It has been shown that mouse and human EGF compete identically with [ ${ }^{125}$ I]labeled mouse EGF for binding to receptors on human placental membranes (24) and with similar potency in human foreskin fibroblasts (15). It has not been determined whether mouse and human EGF compete identically with $\left[{ }^{125} \mathrm{I}\right]$ labeled mouse EGF for binding to AG2804 fibroblasts, but we have obtained indirect evidence in support of this conclusion. Using AG2804 cells and

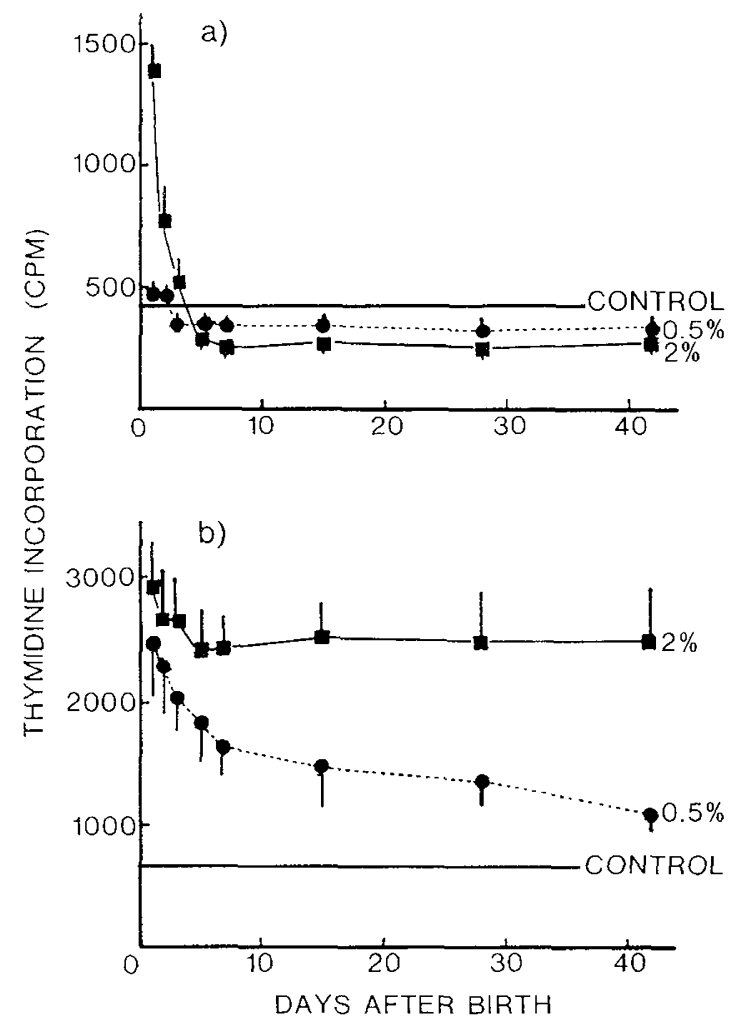

Fig. 5. Effects of $0.5 \%$ and $2 \% \mathrm{v} / \mathrm{v}$ human milk on DNA synthesis in cultured cells. Rates of DNA synthesis are expressed as counts/min of $\left[{ }^{3} \mathrm{H}\right]$ thymidine incorporated into trichloroacetic acid-insoluble material. Data are normalized to the mean control rate, as described for protein synthesis (Figure 4). a) L6 myoblasts. Values are mean \pm SEM for four to five measurements. In the presence of $5 \% \mathrm{v} / \mathrm{v}$ fetal calf serum, the rate of thymidine incorporation was $3392 \pm 502$ counts/min $(n=5)$. b) T47D breast cancer cells. Data are given as mean \pm SEM for $3(0.5 \%$ milk) or four to five determinations $(2 \%)$. The rate with $5 \%$ fetal calf serum was $1936 \pm 74$ counts $/ \min (n=5)$ mouse EGF as the standard and tracer, we have measured urinary EGF concentrations in adult men $[7.3 \pm 2.0 \mathrm{nM}, 0.64 \pm$ $0.09 \mathrm{nmol} / \mathrm{mmol}$ creatinine, mean $\pm \mathrm{SEM}, n=9]$ the values of which are similar to those obtained by Nexo et al. (24), who used a radioreceptor assay with human placental membranes and by Uchihashi et al. (33), who used an homologous radioimmunoassay. Furthermore, the concentration of EGF in mature human milk shown in Figure $2 b$ is similar to that determined by radioimmunoassays using human EGF standard (30). It therefore appears likely that human EGF is measured accurately in receptor assays using AG2804 fibroblasts and murine EGF standard.

EGF in human colostrum and mature milk exceeds the serum concentration by 2000 - and 200 -fold, respectively (14). Milk from other species also contains high concentrations of EGF but there is considerable interspecies variation. We have measured 2 $\mathrm{nM}$ EGF in cow colostrum and $10-20 \mathrm{nM}$ in colostrum from pigs and sheep whereas mature mouse milk is reported to contain 33-66 nM EGF (6). The insulin concentration in milk also varies between species: sheep, cow, and human colostrum contain 2.-3 $\mathrm{nM}$ insulin but pig colostrum contains approximately $10 \mathrm{nM}$ insulin. In addition to these differences among species, we have observed a high degree of variability among individual donors in the protein, insulin and EGF concentrations in human colostrum. This is probably due, in part, to the time of sampling. Most mothers provided only one sample of colostrum, expressed within $12 \mathrm{~h}$ after birth. In cases where more than one sample was provided, it was clear that insulin, EGF, and protein declined markedly within several hours of the onset of lactation, a change also observed in sheep, cow, and pig colostrum. Nevertheless, the time of sampling cannot account for most of the variability because we have measured a wide range of EGF and insulin concentrations after quantitative collection of colostrum from sheep and cows under conditions where suckling was not permitted.

It has not been clearly established whether insulin and EGF in milk originate from blood or are synthesised in the mammary gland. Beck and Tucker (3) calculated from arteriovenous differences and milk production rates that insulin in cow's milk can be derived entirely from the blood, a conclusion supported by Cevreska et al. (8) who reported a close correlation between insulin concentrations in human plasma and milk. Less information is available on the origin of EGF but it has been shown that radioactively labeled EGF can pass from the circulation into milk (4).

We have shown that human milk stimulates protein and DNA synthesis in several lines of cultured cells and, in agreement with previous studies using bovine milk $(2,18,31)$, colostrum has a much higher activity than mature milk. It has been reported for some cell lines that insulin (2) or EGF (7) can account for most of the mitogenic activity of milk. Although Figures 4 and 5 show that changes in the growth-promoting activity of milk in L6, 3T3-L1, and T47D cells parallel the fall in insulin and EGF, it is apparent from Table 2 that the cell lines show little response to either insulin or EGF in the range of concentrations found in milk. Colostrum must, therefore, contain high concentrations of additional growth factors. Preliminary evidence suggests that

Table 2. Stimulation of protein and DNA synthesis in cultured cells by human milk, epidermal growth factor (EGF), and insulin

\begin{tabular}{|c|c|c|c|c|}
\hline & \multicolumn{2}{|c|}{ Protein synthesis $\%$ above control rate } & \multicolumn{2}{|c|}{ DNA synthesis \% above control rate } \\
\hline & L6 myoblasts & 3T3-LI fibroblasts & L6 myoblasts & $\begin{array}{c}\text { T47D breast cancer } \\
\text { cells }\end{array}$ \\
\hline $2 \%$ Mature milk* & 28 & 72 & 0 & 286 \\
\hline $\begin{array}{l}10^{-10} \mathrm{M} \mathrm{EGF}+10^{-11} \mathrm{M} \\
\text { insulin }\end{array}$ & 0 & 0 & 0 & 0 \\
\hline $2 \%$ colostrum & 117 & 229 & 215 & 352 \\
\hline $\begin{array}{l}10^{-9} \mathrm{M} \mathrm{EGF}+5 \times 10^{-11} \mathrm{M} \\
\text { insulin }\end{array}$ & 0 & 24 & 0 & 79 \\
\hline
\end{tabular}

* Data for mature milk (d 42-44 of lactation) and colostrum (d 1) were calculated from values in Figures 4 and 5. 
insulin-like growth factors may occur in high concentrations in human and bovine colostrum and could be responsible for most of the growth-promoting activity of milk in L6, 3T3-L1 and T47D cells. Insulin is mitogenic in these cell lines only at unphysiologically high concentrations $\left(10^{-7} \mathrm{M}\right)$ which permit insulin binding to a receptor specific for insulin-like growth factors (35) and we have also found that protein metabolism in L6 myoblasts and 3T3-L1 fibroblasts is sensitive to regulation by the insulin-like growth factors (results not shown).

Although the concentrations of insulin and EGF fall sharply during the first few days of lactation, the volume of milk produced correlates inversely with these changes so it appears likely that the infant would ingest large amounts of growth factors throughout lactation. The occurrence of high concentrations of these factors in human milk suggests that they may be important for the growth and differentiation of infant tissues. Growth factors may play a role in the proliferation and maturation of the gut without necessarily entering the circulation and in support of this, both insulin $(22,29)$ and EGF $(1,21,29)$ have been shown to regulate the development of the intestinal mucosa of suckling mice and rats. In addition, growth factors in milk may, at least initially, cross the intestinal wall to regulate the development of a variety of other tissues. There is some evidence that growth factors can accelerate the growth of the newborn. Infants born with transient diabetes show growth retardation (27) whereas anabolic actions of insulin-like growth factors in the postnatal animal have been reported (13) and injection of EGF into fetal lambs produces a variety of maturation reactions $(5$, 32). Nevertheless, a physiologic role for milk growth factors requires direct contact with target tissues. There is little information available on the intestinal uptake of protein hormones, especially in humans and other species that acquire maternal immunoglobulin via the placenta rather than postnatally (34). It has been reported that in rabbits, bovine serum albumin is transported intact from the gut to the plasma for several weeks after birth (34) whereas studies in mice $(9,16)$, rats $(23)$, and lambs (25) have shown that insulin, prolactin, and EGF can cross the intestinal wall of the newborn and influence development. It is feasible therefore, that in the initial stages of lactation, growth factors in human milk may enter the circulation of the infant, intact, to regulate growth. If milk-borne growth factors are important to the infant's development, the marked differences among species in insulin and EGF concentrations in milk suggest that feeding of cow's milk or synthetic formulations may not provide optimal conditions for the growth of the newborn.

Although this indirect evidence suggests the importance of milk growth factors in the development of the infant, the possibility must be considered that their primary role is related to proliferation and maintenance of the lactating breast. They may also occur in milk as an excretory product. A role in the growth of breast tissue is suggested by the high sensitivity of T47D breast cancer cells to human milk. Furthermore, a physiologic role for EGF need not be invoked to explain its high concentration in milk because the concentration of EGF excreted in urine (33) is similar to that in mature milk (Fig. 2b). Feeding trials with partially purified growth factor preparations and infusion or perfusion studies on intestinal uptake should resolve some of these problems and provide more direct information on the functions of growth factors in milk.

\section{REFFRENCES AND NOTES}

1. Al-Vaffusi A. I. and Wright $\mathrm{N}$. A.: The effect of epidermal growth factor (EGF) on cell proliferation of the gastro-intestinal mucosa in rodents. Virchows Arch. (Cell Path.). 40:6.3 (1982)

2. Ballard F. J.. Nicld M. K.. Francis G. L.. Dahlenburg G. W.. and Wallace J. C.: The relationship between the insulin content and inhibitory effects of bovine colostrum on protein breakdown in cultured cells. J. Cell. Physiol., 110: $249(1982)$.

3. Beck N. F. G., and Tucker H. A.: Mammary arterial and venous concentration of serum insulin in lactating dairy cows. Proc. Soc. Exp. Biol. Med.. 159. 394 (1978).
4. Blakeley D. M.. Brown K. D.. and Fleet I. R.: Transfer of epidermal growth factor from blood to milk in lactating goats. J. Physiol. (London), 326: 57P (1982).

5. Blum P. M.. Phelps D. L.. Ank B. J.. Krantman H. J., and Stiehm E. R.: Survival of oral human immune serum globulin in the gastrointestinal tract of low birth weight infants. Pediatr. Res., I5: 1256 (1981).

6. Byyny R. L... Orth D. N.. Cohen S., and Doyne E. S.: Epidermal growth factor: Effects of androgens and adrenergic agents. Endocrinology, 95: 776 (1974).

7. Carpenter $G$.: Epidermal growth factor is a major growth-promoting agent in human milk. Science. 210: 198 (1980).

8. Cevreska S., Kovacev V. P.. Stankovski M.. and Kalamares E.: The presence of immunologically reactive insulin in milk of women, during the first week of lactation and its relation to changes in plasma insulin concentration. God. Zb. Med. Fak. Skopje. 21: 35 (1975).

9. Cohen S. and Taylor J. M.: Epidermal growth factor: chemical and biological characterisation. Rec. Prog. Horm. Res.. 30: 533 (1974).

10. Dulley J. R. and Grieve P. A.: A $\leqslant$. nple technique for eliminating interference by detergents in the Lowry method of protein determination. Anal. Biochem.. 64: 136 (1975).

11. Fraker P. J., and Speck J. C. (Jr.): Protein and cell membrane iodination with a sparingly soluble chloramide, 1.3.4.6-tetrachloro-3 $\alpha .6 \alpha$-diphenylglycouril. Biochem. Biophys. Res. Comm.. 80:849 (1978).

12. Hales C. N. and Randle P. J.: Immunoassay of insulin with insulinantibody precipitate. Biochem. J.. 88: 137 (1963).

13. Hill D. J. and Milner R. D. G.: Somatomedins and fetal growth. In: Ciba Foundation Symposium 86: Somatomedins and Fetal Growth. pp. 124-151 (Pitman Ltd.. London, 1981).

14. Hirata Y.. Moore G. W.. Bertagna C., and Orth D. N.: Plasma concentration of immunoreactive human epidermal growth factor (urogastrone) in man. J. Clin. Endo. Metab., 50:440 (1980).

15. Hollenberg M. D. and Gregory H.: Epidermal growth factor-urogastrone: biological activity and receptor binding of derivatives. Molec. Pharmacol.. 17: 314 (1980).

16. Kelly W. A.: Passage of insulin through the wall of the gastrointestinal tract of the infant mouse. Nature. 186:971 (1960).

17. Klagsbrun M.: Human milk stimulates DNA synthesis and cellular proliferation in cultured fibroblasts. Proc. Natl. Acad. Sci. U.S.A., 75: 5057 (1978).

18. Klagsbrun M. and Neumann J.: The serum-free growth of Balb/c $3 T 3$ cells in medium supplemented with bovine colostrum. J. Supramol. Struct.. 1/: 349 (1979).

19. Knowles S. E., Gunn J. M., Hanson R. W., and Ballard F. J.: Increased degradation rates of protein synthesised in hepatoma cells in the presence of amino acid analogues. Biochem. J.. 146: 595 (1975)

20. Koldovsky O.: Hormones in milk. Life Sci., 26: 1833 (1980).

21. Malo C and Menard D.: Influence of epidermal growth factor on the development of suckling mouse intestinal mucosa. Gastrocnterology, 83: 28 (1982).

22. Menard D.. Malo C., and Calvert R.: Insulin accelerates the development of intestinal brush border hydrolytic activities of suckling mice. Develop. Biol., 85: $150(1981)$

23. Mosinger B.. Placer Z.. and Koldovsky O.: Passage of insulin through the wall of the gastro-intestinal tract of the infant rat. Nature. 184: 1245 (1959).

24. Nexo E.. Lamberg S. 1.. and Hollenberg M. D.: Comparison of a receptor binding assay with a radioimmunoassay for measuring human epidermal growth factor-urogastrone in urine. Scand. J. Clin. Lab. Invest., 41: 577 (1981).

25. Pierce A. E., Risdall P. C., and Shaw B.: Absorption of orally administered insulin by the newlyborn calf. J. Physiol.. 171: 203 (1964).

26. Schade D. S. and Eaton R. P.: Role of insulin and glucagon in obesity. Diabctes, 23: 657 (1974).

27. Schiff D.. Colle E., and Stern L.: Metabolic and growth patterns in transient nconatal diabetes. New Eng. J. Med.. 287: 119 (1972).

28. Serani $A$. and Baserga R.: Routine growth of cell lines in medium supplemented with milk instead of serum. Cell Biol. Intl. Rep.. 5: 339 (1981).

29. Simon P. M.. Kedinger M., Raul F., Grenier J. F., and Haffen K.: Organ culture of suckling rat intestines: comparative study of various hormones on brush border enzymes. In Vitro. 18: 339 (1982).

30. Starkey R. and Orth D. N.: Radioimmunoassay of human epidermal growth factor (urogastrone). J. Clin. Endo. Metab., 45: 1144 (1977).

31. Steimer K. S.. Packard R., Holden D. and Klagsbrun M.: The serum-free growth of cultured cells in bovine colostrum and in milk obtained later in the lactation period. J. Cell. Physiol., 109: 223 (1981).

32. Sundell H. W., Gray M.E. Serenius F.S. Escobedo M.B.. and Stahlman M. T.: Effects of epidermal growth factor on lung maturation in fetal lambs. Amer. J. Pathol.. 100: 707 (1980).

33. Uchihashi M.. Hirata Y.. Fujita T.. and Matsukura S.: Age-related decrease of urinary excretion of human epidermal growth factor (hEGF). Life Sci., 31: $679(1982)$

34. Udall J. N., Pang K.. Kritze L., Kleinman R., and Walker W. A.: Development of gastrointestinal mucosal barrier. I. The effect of age on intestinal permeability to macromolecules. Pediatr. Res.. 15:241 (1981).

35. Zapf J.. Rinderknecht E.. Humbel R. E., and Froesch E. R.: Non suppressible insulin-like activity (NSILA) from human serum: recent accomplishments and their physiologic implications. Metabolism. 27: 1803 (1978).

36. We thank Paula Gravestock for tcchnical assistance and Judy Burgoyne and Anne Fitzgerald for collection of milk samples. We are grateful to all mothers who provided these samples and for the assistance of the Nursing Mothers 
Association and the Mothers and Babies Health Association of South Australia.

37. Requests for reprints should be addressed to: Dr. Leanna C. Read. CSIRO Division of Human Nutrition. Kintore Avenue. Adelaide. South Australia 5000. Australia.
38. This work was supported by grants from the Clive and Vera Ramaciotti Foundations and the Rural Credits Development Fund. 39. Received for publication November 9.1982.

40. Accepted for publication April 19,1983.

\title{
Measurement of Total Respiratory Resistance in Children by a Modified Forced Oscillation Method
}

\author{
ELIEZER NUSSBAUM ${ }^{(15)}$ AND STANLEY P. GALANT \\ The Pediatric Pulmonary Division, Miller Children's IIospital Medical Center and the Department of Pediatrics. \\ University of California, Irvine, California, USA
}

\section{Summary}

Total respiratory resistance $\left(R_{1}\right)$ was measured in 11 normal children, 2-5.5 years of age (mean 4.16 years), and in 24 children with bronchial asthma, 2-10.5 years of age (mean 6 years), by oscillating the respiratory system from $2-32 \mathrm{~Hz}$ with a new microprocessor technique. Twenty-five children were $\leq 5$ years of age. This technique was also compared with airway resistance (Raw) by body plethysmography both in terms of baseline values and response to bronchodilators. The absolute values for Raw are lower than $\mathbf{R}_{\mathrm{T}}$ with a mean percentage difference ( \pm S.E.M.) of $30.3 \pm 5.0 \%$; however, good correlation between the two techniques was obtained $(r=0.79)$. The changes of $R_{T}$ and Raw were not significantly different after aerosolized isoproterenol $(P$ $>0.05$ ). We determined the inverse relationship between height and $R_{T}$ with correlation coefficient $r=-0.79(P<0.01)$. In children, resonant frequency ranged from 6-24 Hz with a mean value of $16.57 \pm 0.78 \mathrm{~Hz}$. The forced oscillation method utilized clinically in this study provides an alternative to total body plethysmography or an esophageal balloon, which are technically difficult and preclude their routine use in small children.

In conclusion, $R_{1}$ utilized in this study is a rapid and reproducible approximation of Raw. It allows evaluation of $R_{T}$ over a wide range of frequencies including resonant frequency and requires less cooperation than body plethysmography. It requires a relatively short time and allows objective assessment of obstructive airway disease and its responsiveness to bronchodilators in children under 5 years of age.

\section{Abbreviations}

F.O., forced oscillation

$f_{r}$, resonant frequency

Hz, Hertz, which equals cycles per second

Raw, airway resistance

$\mathbf{R}_{\mathrm{T}}$, total respiratory resistance

Objective assessment of obstructive airway disease requires cooperation and therefore has limited use in children under 6 years of age. In this age group the distinction between normals and those with airway obstruction such as asthmatics or cystic fibrosis patients usually has been based on clinical evaluation. Furthermore, in those children who were diagnosed as having bronchial asthma, the degree of their obstructive airway reversibility after treatment with bronchodilators could not be evaluated nor followed objectively.

Measurements of total respiratory resistance $\left(R_{T}\right)$ by oscillating a sine wave of airflow to the mouth was first described by DuBois et al. $(3,4)$ and later applied to children $(2,9,11-13)$. This F.O. method has been utilized clinically and provides an alternative to total body plethysmography or an esophageal balloon, both of which are technically difficult and therefore preclude routine use in small children. Because $\mathrm{R}_{\mathrm{T}}$ is the sum of airway resistance and tissue resistance (including chest wall), values should approximate total lung resistance by the esophageal balloon $(2,5$, 6).

The F.O. technique is based on the theory that when a sine wave of airflow is applied to the tracheobronchial tree during spontaneous breathing, the changes in transthoracic pressure are directly related to the total impedance of the system $(2,5,6)$. The total impedance is composed of three elements: effective resistance, inertia, and elastic compliance $(5,6)$. At very low frequencies, less than $2 \mathrm{~Hz}$, elastic impedance dominates but at very high frequencies (above $10 \mathrm{~Hz}$ ) inertial impedance dominates $(2,5-7)$. Between $5-25 \mathrm{~Hz}$, (called the resonant frequency) the inertial and elastic components are of equal magnitude and opposite in sign, and therefore cancel each other. At resonant frequency, pressure and flow are in phase (zero phase angle). Total respiratory resistance can then be calculated from the relationship between pressure and flow, both measured at the mouth of the subject $(4,5,7)$. The mathematical expression of pressure change across the respiratory system include:

$$
\Delta \mathrm{P}=\frac{\mathrm{I}}{\mathrm{C}} \cdot \mathrm{V}+\mathrm{R} \dot{\mathrm{V}}+\mathrm{I} \ddot{\mathrm{V}}
$$

where $\Delta \mathrm{P}$ represents pressure change, $\mathrm{V}$, the resulting volume; $\dot{V}$, the flow rate; $\ddot{V}$, the volume acceleration; $\mathrm{C}$, the total respiratory compliance; $\mathrm{R}$, the flow resistance; and $\mathrm{I}$, the mass inertia. At resonant frequency $\Delta \mathrm{P}=\mathrm{R} \dot{\mathrm{V}}$ and therefore $\mathrm{R}=\frac{\Delta \mathrm{P}}{\dot{\mathrm{V}}}$. 